\title{
Trude Lorentzen fikk Olaf-prisen 2014
}

Ved Hanne Holmesland

Olaf-prisen for 2014 gikk til journalist Trude Lorentzen for hennes bidrag til $\varnothing \mathrm{kt}$ åpenhet om selvmord i samfunnet gjennom sin bok Mysteriet mamma. Med sin sterke fortelling har boken nådd brede lesergrupper og bidratt til $\phi k t$ forståelse for barns og ungdommers opplevelse av psykisk sykdom hos foreldre, suicidal atferd og tap.

Lorentzen har varmt, klokt og positivt satt et alvorlig samfunnsproblem på dagsordenen, på en måte som kommer berørte barn, ungdommer og deres familier til gode.

\section{TRUDE LORENTZEN MYSTERIET MAMMA}

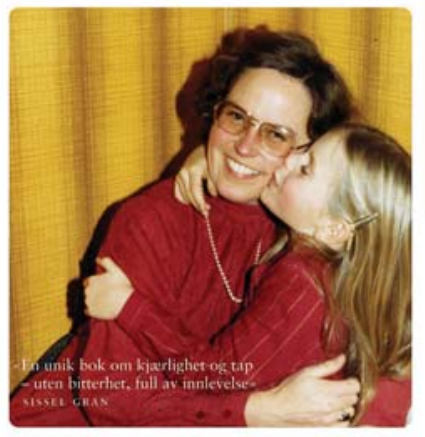

Iår ble Olaf-prisen delt ut under et åpent møte om forebygging av selvmord på Litteraturhuset i Oslo 8. september -i forbindelse med markeringen av Verdensdagen for selvmordsforebygging. Prisvinneren leste fra boken og fortalte om prosessen rundt skrivingen.

Deretter var det tid for premiere på den nye filmen Leve, et samarbeidsprosjekt mellom Olafs minnefond, Norges R $\varnothing$ de Kors og Unge LEVE. I filmen forteller fire unge åpent og direkte om sine selvmordsfors $\varnothing \mathrm{k}$, hva som bragte dem dit og hvordan de har kommet seg videre i livet.

Programmet for det åpne møtet rommet også en fantastisk minikonsert med Ingrid Olava og foredrag ved Lars Mehlum og Heidi Tessand.
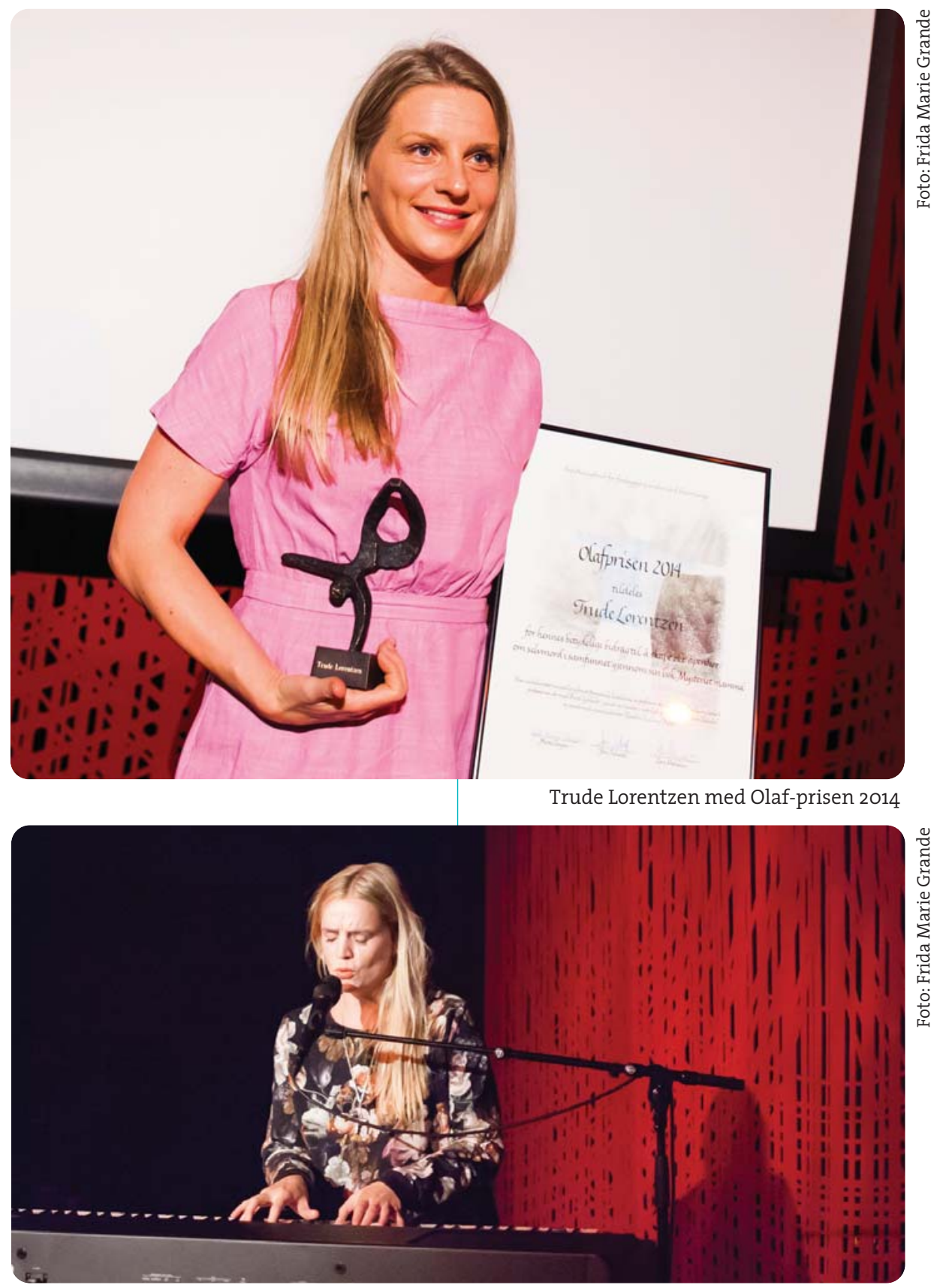

Ingrid Olava

I forkant av arrangementet var det boklansering av Signe Narvesens "La oss snakke om det - når unge mennesker mister livslysten". I boken har fem ungdommer bidratt med sin historie, og den adresserer åpenhet .

Olaf-prisen er etablert og deles ut av Stiftelsen Olafs Minnefond til forebygging av selvmord blant unge.
Prisen tildeles som en anerkjennelse til en person som har bidratt med fremragende vitenskapelig arbeid eller kunnskapsformidling innenfor feltet selvmordsforebygging blant barn og ungdom, og deles ut hvert år, fortrinnsvis i forbindelse med markering av Verdensdagen for selvmordsforebygging. Et fagutvalg ledet av professor dr.med. Lars Mehlum har vurdert foreslåtte kandidater og foretatt innstillingsarbeidet på vegne av stiftelsen. 